International Journal of Natural Disasters \& Health Security (IJNHS)

ISSN 2572-7540

\title{
Ebola - its possibility of bioterrorism and biocrime
}

VirojWiwanitkit

Editorial

Professor, Senior Consultant, Public Heath Curriculum, SurinRajabhat University, Surin, Thailand.

\section{*Corresponding Author:}

VirojWiwanitkit M.D.

Professor,

Wiwanitkit House, Bangkok, Thailand 10160.

E-mail:wviroj@yahoo.com

Received: October 10, 2014

Published: October 14, 2014

Citation: VirojWiwanitkit (2014) Ebola - its possibility of bioterrorism and biocrime. Int J Natural Disaster Health Secur, 1:001e

doi: http://dx.doi.org/10.19070/2572-7540-140001e

Copyright: VirojWiwanitkit ${ }^{\circledR} 2014$. This is an open-access article distributed under the terms of the Creative Commons Attribution License, which permits unrestricted use, distribution and reproduction in any medium, provided the original author and source are credited.

The problem on 2014 Ebola virus outbreak in Africa lead a great concern to the medical society. This disease is believed to be one of the most serious infection in the medical history. The high virulence of Ebola virus is observed and the medical society fears for its possible worldwide pandemic. In addition to the natural spreading, the possibility of artificial outbreak due to bioterrorism and biocrime should be mentioned. In fact, the new emerging disease is an important focus in biological welfare [1]. Werner noted that "an infectious cause has been demonstrated (or strongly suspected) for various diseases and the scope of infectiology keeps widening, while the threat of bioterrorism cannot be neglected [2]." For the case of Ebola, the concern on the illegal use of the virus as the new bioterrorism agent by the terrorist is widely discussed [3]. Ebola virus can cause hemorrhagic fever that is easy for using as potential agents for biologic warfare due to "capability of aerosol transmission, high morbidity,and mortality associated with infection, and ability to replicate in cell culture in high concentrations [4]." Due to the high infectivity, the infection control is required and this should extend to control for the possible illegal use of the virus as the bioterrorism agent [5]. Cunha noted that knowledge on this new viral disease is needed because the case might primarily present to the emergency room without previous notification [6]. Cunha said that the practitioner needed to know "the clinical presentation and differential diagnosis of potential bioterrorist agents when first presenting to the hospital in the emergency room setting [6]." A specific guideline should be prepare for fighting the possible bioterrorism due to Ebola virus. The good example is "Bichat guidelines for the clinical management of haemorrhagic fever viruses and bioterrorism-related haemorrhagic fever viruses [7]." According to this guideline, "all patients must be isolated and receive intensive supportive therapy [7]."

\section{References}

[1]. Jansen HJ, Breeveld FJ, Stijnis C, Grobusch MP (2014) Biological warfare, bioterrorism, and biocrime.ClinMicrobiol Infect 20(6):488-96.

[2]. Werner GH (2001) The worldwide challenges of "new" or reemerging communicable diseases at the dawn of the 21 st century.Ann Pharm Fr. 59(4):246-77.

[3]. Strauss $S$ (2014) Ebola research fueled by bioterrorism threat

[4]. Salvaggio MR, Baddley JW (2004) Other viral bioweapons: Ebola and Marburg hemorrhagic fever.DermatolClin. Jul;22(3):291-302.

[5]. Polesky A (2003) Bhatia G.Ebola hemorrhagic fever in the era of bioterrorism.SeminRespir Infect 18(3):206-15.

[6]. Cunha BA (2002) Anthrax, tularemia, plague, ebola or smallpox as agents of bioterrorism: recognition in the emergency room.ClinMicrobiol Infect 8(8):489-503.

[7]. Bossi P, Tegnell A, Baka A, Van Loock F, Hendriks J et al (2004) Task Force on Biological and Chemical Agent Threats, Public Health Directorate, European Commission, Luxembourg. Bichat guidelines for the clinical management of haemorrhagic fever viruses and bioterrorism-related haemorrhagic fever viruses.Euro Surveill 15;9(12):E11-2. 